\title{
CHANGES IN SPRING ARRIVAL DATES OF CENTRAL EUROPEAN BIRD SPECIES OVER THE PAST 100 YEARS
}

\author{
LÁszló Bozó ${ }^{1}$ and Tibor Csörgő ${ }^{2}$ \\ ${ }^{1}$ Department of Systematic Zoology and Ecology, Eötvös Loránd University \\ 1117 Budapest, Pázmány Péter sétány 1/c, Hungary; \\ E-mail: bozolaszlo91@gmail.com, https://orcid.org/0000-0002-3047-6005 \\ ${ }^{2}$ Department of Anatomy, Cell- and Developmental Biology \\ Eötvös Loránd University, 1117 Budapest, Pázmány Péter sétány 1/c, Hungary \\ E-mail: csorgo@elte.hu, https://orcid.org/0000-0002-7060-9853
}

Over the past decades, spring temperatures have increased in temperate regions, which resulted in birds arriving earlier in spring. Nonetheless, the timing of some species' spring migration relies on endogenous rhythms that are not affected by climate change. In this study, we analysed changes in the spring arrival dates of 36 bird species over two periods in 22 towns and villages in Southeast Hungary and West Romania. The first period covered the national spring migration counts between 1894 and 1926, while the second period took place between 2005 and 2019 and is based on our recent observation data. Our results show that the average spring arrival dates of most long-distance migrant species have not changed significantly over the past 100 years. In contrast, in cases of medium- and shortdistance migrants, most species arrive earlier recently than in the late 19th and early 20th centuries. This may be caused by the fact that the migration habit of long-distance migrants is characterized by strong genetic determinants, so they can not react as quickly to the warmer spring weather in Europe as the medium- and short-distance migrants. However, in cases of some long-distance migrants, the timing of spring migration changed due to the drying of wintering grounds.

Key words: climate change, spring migration, Csanádi-hát, Partium.

\section{INTRODUCTION}

Nature is a complex and dynamic network organised by species and their interactions (Olesen et al. 2011). Being dynamic, these systems are often characterized by long-term variations. Changes in environmental factors, such as habitat degradation (EwERs \& DidHAm 2006) or the altered food availability (e.g. SıIKAM ̈̈KI 1998) are important components of long-term temporal variations, but salinity (LiN et al. 2001), the concentration of minerals in water (Li et al. 2007), and anthropogenic factors (e.g. pollution) (Woodwell 1970, CLARK \& FrID 2001) could have effects on the ecosystems. However, there may be different factors behind these changes, in the recent years, researchers have focused on increasing temperatures and related climate change, and its effects on the environment (HAUNSCHILD et al. 2016).

Over the past decades, spring temperatures in temperate regions have increased, which resulted in birds arriving earlier in spring and later in au- 
tumn (Menzel et al. 2006, Gordo 2007). A shift to the advanced breeding season can also be observed in several bird species (e.g. CRICK et al. 1997, VISSER et al. 1998, Вотн \& MARvelde 2007). The rate of climate warming has been more gradual in eastern North America than in Europe (HANSEN et al. 2006), and the temporal shifts in avian migration are less obvious (MacMrnowski \& Root 2007, MacMynowski et al. 2007, Miller-Rushing et al. 2008a).

An increasing number of studies reported shifts in the timing of bird migration during the last decades, especially since the 1970's (HUIN \& SPARKS 1998, Cотton 2003, Lehikoinen et al. 2004, Van Buskirk et al. 2009, KNudsen et al. 2011). However, the timing of spring migration in some species could principally be mediated by the factors that are not affected by climate change (e.g. endogenous rhythms, day-length variation on the wintering ground), especially in long-distance migrant species (BERTHOLd 1996, 2001, GwinNer 1996, Both \& Visser 2001, Coppack \& Bотн 2002, Nott et al. 2002, Tryjanowski et al. 2002, Hubálek 2004, Miller-Rushing et al. 2008a, Kullberg et al. 2015). Food supply in the breeding grounds is also a very important regulator of the longdistance migrants. Early migrants generally face low food abundance, but over the course of the arrival period overall food abundance increase (Sмітн \& Moore 2005). Short-distance migrants have also been shown to display a more flexible behavioural response to the local weather at stopover sites (CALVERT et al. 2012).

The majority of these studies concern the last fifty years, a period when global warming has increased after 30-years of stagnation (HANSEN et al. 2005, 2006, Rahmstorf 2008). Historical data on bird migration phenology before the middle of the 20th century, when a significant global warming started (HANSEN et al. 2006), are scarce, but there are some studies from Sweden (KulLBERG et al. 2015), Britain (SPARKs 1999) and the USA (Ellwood et al. 2010). Most monitoring programs have began in the 1960-1980s, but a few go back to the early 20th century or before (ButLer 2003, Hüppop \& Hüppop 2003, HubáleK 2004, GoRDo 2007). These data have been used primarily to test for changes in the timing of migration.

In Hungary, bird observation has long traditions, for example, the first Ornithological Centre of the world was established in Hungary in 1893, but there are many data and publications that date back to even earlier (www.arcanum.hu). According to the intensity of data collection by the Ornithological Centre in Hungary (see Bozó 2017a), we used data of spring arrival dates from 1894-1926 of 36 migratory bird species. In this study, we compared these data with our recent field observation data to examine whether the spring arrival dates of the first individuals varied between the two periods. We also investigated the possible correlation between the earliest arrival dates of the species and the average monthly temperature values. 
We predicted that the spring arrival dates shifted earlier in short-distance migrants, but in the case of long-distance migrants a species-specific pattern is likely to occur. In addition, we assume that arrival time is related to the local temperature. In North America, as a result of climate change, milder winters with less snow, more variable and intense precipitation events and a shorter snow season, species overwinter in higher numbers in the northern regions. Also new species have the opportunity to overwinter there (PRINCÉ \& ZuCKERBERG 2014). For this reason, we have also collected data on species that recently overwinter in the study area regularly but have only been observed occasionally in the winter periods of the late 19th and early 20th centuries.

\section{MATERIAL AND METHODS}

We used data from two different time periods. The first one (Period 1) took place between 1894 and 1926, while the second (Period 2) between 2005 and 2019.

We collected data from Period 1 from the area of the Csanádi-hát and Partium (Southeast Hungary and West Romania), in a circle of $40-45 \mathrm{~km}$ from Kevermes. The area is dominated by flatland plain and low mountains (up to 836 meters) and covers the following settlements: Battonya, Csanádpalota, Dombiratos, Elek, Kunágota, Arad (Oradea), Aradkövi (Cuvin), Kisjenő (Chișineu-Criș), Kispereg (Peregu Mic), Lippa (Lipova), Máriaradna (Radna), Ottlaka (Grăniceri), Pankota, Ópálos (Păuliș), Pécska (Pecica), Sikló (Șiclău), Solymosvár (Șoimoș), Szentpál (Sânpaul), Tornya (Turnu) and Világos (Șiria). All data from Period 1 were published in the journal Aquila (Magr. Orn. Központ 1895, GaAl 1896, 1897, 1898, SCHenk 1899, 1901, 1905, 1906, 1907, 1908, 1909, 1914, 1915, 1916, 1919, 1920, 1921, VeZÉNYI 1902, 1903, 1905, Greschiк 1910, Lambrecht 1911, 1912, 1913, Неgyғoкy 1917, Warga 1922, 1924, 1926, 1928). Arrival dates from Period 2 are from the area of Kevermes and Lőkösháza in Southeast Hungary. Detailed description of the study sites and the data collection can be found in Bozó (2017b). We collected 897 data from Period 1 and 298 data from Period 2.

For the analyses, we used the first field observation record of each species in each year. In studies dealing with long-term changes in spring migration phenology, researchers used the mean or median date of spring migration instead of the first arrival date which may be affected by both population size of the species and sampling effort (TRYJANOwSKI \& Sparks 2001, Miller-Rushing et al. 2008b). However, historical data sets usually include only the arrival time of the first birds and do not provide information on the median date of migration (Kullberg et al. 2015). Therefore, these studies are based on the first observation dates. In the case of Period 1, we used the first arrival dates from all available settlements, therefore, some species have more data than study years. The study species are listed in Table 1. It was not possible to separate the members of the local breeding birds from the migrants, therefore, in this study we consider the research area as a stopover site.

In each species, we calculated the mean values of the first arrival dates for both periods and to decide whether arrival dates differ between the two periods, we used twosample t-probe. We also compared the shifts in arrival dates between the two periods for the species belonging to the two migration strategy groups by two-sample t-probe. In the case of the 11 species of which we have at least 15 data from Period 1, we tested the correlations between the earliest arrival dates and the average monthly temperature values by Pearson correlation. Average monthly temperature values were calculated from the mean 
daily temperatures. Monthly temperature values were obtained from the website of the National Meteorological Service (www.met.hu) and are derived from the regional temperature values of the study area. We used the temperature values of the months when the species arrived to the study area. We decided to use local weather data rather than values representing a larger spatial scale because some of these species never breed in the study area and therefore primarily used it as a stopover site. Arrival at or departure from the stopover site vary depending on the local weather (e.g. DänHARDT \& LindSTRöm 2001).

\section{RESULTS}

The mean spring arrival dates of the 36 study species between 1894-1926 (Period 1) and 2005-2019 (Period 2) are shown in Table 1.

Table 1. Mean spring arrival dates of the study species. Range means the earliest and the latest observation records (Month/Day), SD is the standard deviation, $\mathrm{N}$ is the number of the observation records while Pe is Period.

\begin{tabular}{|c|c|c|c|c|c|c|c|c|}
\hline \multirow[t]{2}{*}{ Species } & \multicolumn{2}{|c|}{ Mean } & \multicolumn{2}{|c|}{ Range } & \multicolumn{2}{|c|}{ SD } & \multicolumn{2}{|c|}{$\mathrm{N}$} \\
\hline & Pe1 & Pe2 & Pe1 & $\mathrm{Pe} 2$ & Pe1 & Pe2 & Pe1 & Pe2 \\
\hline Nycticorax nycticorax & 4.12 . & 4.8. & 4.2.-4.24. & 3.15.-4.30. & \pm 10.1 & \pm 14.2 & 4 & 10 \\
\hline Sylvia atricapilla & 4.12. & 3.30. & 4.12.-4.16. & 3.20.- 4.10. & \pm 2.8 & \pm 6.2 & 2 & 13 \\
\hline Motacilla alba & 3.13. & 3.4. & 2.13.-4.1. & 2.16.-3.22. & \pm 9.3 & \pm 12.4 & 48 & 12 \\
\hline Vanellus vanellus & 3.16. & 2.23 & 2.12.-4.5. & 2.3.-3.12. & \pm 15.5 & \pm 11.5 & 13 & 13 \\
\hline Actitis hypoleuca & 4.3. & 4.18. & 3.25.-4.12. & 4.4.-4.28. & \pm 7.4 & \pm 9 & 4 & 8 \\
\hline Upupa epops & 4.10. & 3.28 . & 3.17.-4.23. & 3.19.-4.6. & \pm 8.8 & \pm 5.9 & 32 & 8 \\
\hline Saxicola torquata & 3.23 . & 3.5. & 3.17.-4.5. & 2.17.-3.21. & \pm 8.5 & \pm 9.9 & 5 & 9 \\
\hline Phylloscopus collybita & 3.26. & 3.18. & 3.4.-4.8. & 3.3.-4.1. & \pm 10.2 & \pm 7.8 & 19 & 13 \\
\hline Grus grus & 3.17. & 3.5 . & 3.2.-4.9. & $2.25 .-3.22$ & \pm 9.2 & \pm 8.7 & 32 & 12 \\
\hline Scolopax rusticola & 3.11. & 3.24 . & 2.22.-4.4. & 3.5.-4.6. & \pm 8.4 & \pm 14.1 & 47 & 6 \\
\hline Ciconia ciconia & 3.29 . & 3.25 . & 3.4.-4.20. & 3.13.-4.5. & \pm 9.2 & \pm 7.3 & 64 & 13 \\
\hline Luscinia megarhynchos & 4.13. & 4.12. & 4.4.-4.23. & 4.7.-4.22. & \pm 4.7 & \pm 5.5 & 28 & 12 \\
\hline Coturnix coturnix & 4.25 . & 4.26 . & 4.1.-5.10. & 4.8.-5.7. & \pm 8.6 & \pm 10 & 19 & 9 \\
\hline Hirundo rustica & 4.3 . & 3.28 . & 3.16.-4.15. & 3.20.-4.5. & \pm 5.9 & \pm 4.2 & 71 & 14 \\
\hline Oenanthe oenanthe & 4.7. & 4.4 . & 3.26. -4.16 . & 3.28.-4.18. & \pm 8.2 & \pm 5.6 & 6 & 9 \\
\hline Crex crex & 5.2 & 4.22 & 4.17.-5.19. & 4.7.-5.7. & \pm 7.9 & \pm 21.2 & 17 & 2 \\
\hline Cuculus canorus & 4.8 . & 4.17. & 3.21.-4.24. & 4.3.-4.28. & \pm 6.8 & \pm 8.1 & 46 & 12 \\
\hline Falco vespertinus & 4.25 . & 5.1. & $4.18 .-5.5$ & 4.17.-5.17. & \pm 7.1 & \pm 9.6 & 5 & 8 \\
\hline Sylvia borin & 4.21 . & 5.3. & 4.16.-4.30. & 5.1.-5.5. & \pm 7.8 & \pm 2.8 & 3 & 2 \\
\hline Phoenicurus phoenicurus & 4.12. & 4.13. & 4.6.-4.23. & 4.5.-4.18. & \pm 6.7 & \pm 5.4 & 5 & 5 \\
\hline Lanius minor & 5.2. & 5.9 . & 4.24.-5.6. & 5.1.-5.16. & \pm 4.3 & \pm 6.3 & 7 & 9 \\
\hline
\end{tabular}


Table 1 (continued)

\begin{tabular}{lcccccccc}
\hline \multirow{2}{*}{ Species } & \multicolumn{2}{c}{ Mean } & \multicolumn{2}{c}{ Range } & \multicolumn{2}{c}{ SD } & \multicolumn{2}{c}{$\mathrm{N}$} \\
\cline { 2 - 9 } & Pe1 & Pe2 & Pe1 & Pe2 & Pe1 & Pe2 & Pe1 & Pe2 \\
\hline Ficedula hypoleuca & 4.5. & 4.17. & $4.5 .-4.6$. & $4.7 .-4.28$. & \pm 0.7 & \pm 6.1 & 2 & 10 \\
Caprimulgus europaeus & 4.21. & 4.18. & $3.31 .-5.8$. & $4.18 .-4.19$. & \pm 14.7 & \pm 0.7 & 5 & 2 \\
Alauda arvensis & 2.1. & 2.21. & $2.7 .-3.15$. & $2.10 .-3.5$. & \pm 8.1 & \pm 6.3 & 34 & 12 \\
Delichon urbicum & 4.6. & 4.5. & $3.21 .-4.14$. & $3.30 .-4.9$. & \pm 5.1 & \pm 2.6 & 32 & 12 \\
Jynx torquilla & 4.8. & 4.16. & $3.31 .-4.17$. & $4.12 .-4.21$. & \pm 5.6 & \pm 3.8 & 7 & 5 \\
Columba palumbus & 3.7. & 2.28. & $2.1 .-3.26$. & $2.15 .-3.19$. & \pm 14.6 & \pm 7.8 & 13 & 9 \\
Ficedula albicollis & 4.15. & 4.19. & $4.10 .-4.23$. & $4.7 .-4.27$. & \pm 4.9 & \pm 6.7 & 6 & 8 \\
Riparia riparia & 4.17. & 4.10. & $4.9 .-4.28$. & $4.4 .-4.19$. & \pm 6.5 & \pm 5.9 & 8 & 9 \\
Oriolus oriolus & 4.26. & 4.26. & $4.15 .-5.8$. & $4.17 .-5.3$. & \pm 5.1 & \pm 4.9 & 45 & 13 \\
Sturnus vulgaris & 3.4. & 2.19. & $2.20 .-3.21$. & $2.12 .-2.26$. & \pm 8.9 & \pm 4.5 & 27 & 11 \\
Coracias garrulus & 4.23. & 4.30. & $4.16 .-5.3$. & $4.21 .-5.14$. & \pm 6.2 & \pm 12.3 & 7 & 3 \\
Muscicapa striata & 5.5. & 4.28. & $5.1 .-5.7$. & $4.18 .-5.5$. & \pm 3.5 & \pm 5.3 & 3 & 8 \\
Lanius collurio & 5.2. & 4.28. & $4.25 .-5.12$. & $4.22 .-5.3$. & \pm 6.9 & \pm 4.1 & 5 & 10 \\
Streptopelia turtur & 4.20. & 4.21. & $4.4 .-5.2$. & $4.16 .-4.27$. & \pm 5.9 & \pm 3.4 & 36 & 10 \\
Falco tinnunculus & 3.17. & 2.22. & $3.8 .-3.29$. & $2.12 .-3.3$. & \pm 8.8 & \pm 7.1 & 4 & 7 \\
\hline
\end{tabular}

Table 2. Comparison of spring arrival dates of the two study periods. Species with very small sample sizes ( $<3$ years) marked with *. Differences mean the differences between the two periods (mean arrival date of Period 1 - mean arrival date of Period 2). Under migration strategies, SD means the short-distance migrants and LD the long-distance migrants.

\begin{tabular}{lrrcc}
\hline Species & p value & t value & Differences (day) & Migration strategy \\
\hline Nycticorax nycticorax & 0.490 & 0.4 & -4 & LD \\
Sylvia atricapilla & 0.009 & 3.1 & -15 & SD \\
Motacilla alba & 0.007 & 2.8 & -9 & SD \\
Vanellus vanellus & $<0.001$ & 3.9 & -21 & SD \\
Actitis hypoleuca & $<0.014$ & -2.9 & 15 & LD \\
Upupa epops & $<0.001$ & 3.8 & -13 & LD \\
Saxicola torquata & 0.009 & 3.2 & -18 & SD \\
Phylloscopus collybita & 0.020 & 2.5 & -8 & LD \\
Grus grus & $<0.001$ & 3.8 & -12 & SD \\
Scolopax rusticola & $<0.001$ & -3.2 & 13 & SD \\
Ciconia ciconia & 0.142 & 1.5 & -4 & LD \\
Luscinia megarhynchos & 0.692 & 0.1 & -1 & LD \\
\hline
\end{tabular}


Table 2 (continued)

\begin{tabular}{|c|c|c|c|c|}
\hline Species & $\mathrm{p}$ value & $\mathrm{t}$ value & Differences (day) & Migration strategy \\
\hline Coturnix coturnix & 0.897 & -0.1 & 1 & LD \\
\hline Hirundo rustica & 0.001 & 3.5 & -6 & LD \\
\hline Oenanthe oenanthe & 0.418 & 0.8 & -3 & LD \\
\hline Crex crex & 0.143 & 1.5 & -10 & LD \\
\hline Cuculus canorus & $<0.001$ & -4.2 & 9 & LD \\
\hline Falco vespertinus & 0.284 & -1.1 & 6 & LD \\
\hline Sylvia borin ${ }^{*}$ & 0.139 & -1.9 & 12 & LD \\
\hline Phoenicurus phoenicurus & 0.763 & -0.3 & 1 & LD \\
\hline Lanius minor & 0.175 & -1.4 & 7 & LD \\
\hline Ficedula hypoleuca* & 0.027 & -2.6 & 12 & LD \\
\hline Caprimulgus europaeus* & 0.775 & 0.3 & -3 & LD \\
\hline Alauda arvensis & 0.007 & 2.8 & -8 & SD \\
\hline Delichon urbicum & 0.662 & 0.4 & -1 & LD \\
\hline Jynx torquilla & 0.018 & -2.8 & 8 & LD \\
\hline Columba palumbus & 0.195 & 1.3 & -7 & SD \\
\hline Ficedula albicollis & 0.271 & -1.2 & 4 & LD \\
\hline Riparia riparia & 0.032 & 2.4 & -7 & LD \\
\hline Oriolus oriolus & 0.758 & -0.3 & 0 & LD \\
\hline Sturnus vulgaris & $<0.001$ & 4.7 & -13 & SD \\
\hline Coracias garrulus* & 0.295 & -1.1 & 7 & LD \\
\hline Muscicapa striata & 0.102 & 1.8 & -7 & LD \\
\hline Lanius collurio & 0.236 & 1.2 & -4 & LD \\
\hline Streptopelia turtur & 0.790 & -0.3 & 1 & LD \\
\hline Falco tinnunculus & 0.001 & 4.7 & -23 & SD \\
\hline
\end{tabular}

Spring arrival dates were earlier in Period 2 in the case of Common Kestrel, Common Crane, Northern Lapwing, Eurasian Hoopoe, Eurasian Skylark, Barn Swallow, Sand Martin, White Wagtail, European Stonechat, Blackcap, Common Chiffchaff and Common Starling. Spring arrival dates were later in Period 2 in the case of Common Sandpiper, Eurasian Woodcock, Common Cuckoo, Eurasian Wryneck and Pied Flycatcher. There were no significant changes in other cases (Table 2). Short-distance migrants arrive significantly earlier than long-distance migrants in Period $2(t=4.037, \mathrm{p}<0.0001)$.

In Period 1, the earliest arrival dates correlated negatively with monthly temperature in the Eurasian Skylark, while positively in the Common Cuckoo. 
Table 3. Correlations between the arrival dates and the average monthly temperature values.

\begin{tabular}{lcccccc}
\hline Species & $\mathrm{R}$ & $\mathrm{p}$ & $\mathrm{R}$ & & \multicolumn{2}{c}{ Number of years } \\
& Period 1 & $\mathrm{p}$ & Period 2 & $\mathrm{p}$ & Period 1 & Period 2 \\
\hline Ciconia ciconia & -0.335 & 0.108 & -0.131 & 0.670 & 30 & 13 \\
Grus grus & 0.149 & 0.566 & -0.421 & 0.173 & 20 & 12 \\
Streptopelia turtur & 0.208 & 0.377 & -0.402 & 0.249 & 22 & 10 \\
Cuculus canorus & 0.502 & 0.028 & -0.508 & 0.092 & 22 & 12 \\
Alauda arvensis & -0.513 & 0.020 & -0.592 & 0.042 & 21 & 12 \\
Hirundo rustica & 0.130 & 0.544 & 0.317 & 0.269 & 28 & 14 \\
Delichon urbicum & -0.069 & 0.812 & -0.696 & 0.011 & 18 & 12 \\
Motacilla alba & -0.283 & 0.214 & -0.456 & 0.136 & 23 & 12 \\
Luscinia megarhynchos & -0.162 & 0.581 & -0.457 & 0.135 & 15 & 12 \\
Sturnus vulgaris & -0.506 & 0.112 & -0.581 & 0.061 & 15 & 11 \\
Oriolus oriolus & -0.303 & 0.160 & -0.529 & 0.077 & 26 & 12 \\
\hline
\end{tabular}

Table 4. Overwintering species in the Period 1.

\begin{tabular}{lcc}
\hline Species & Year & Location \\
\hline Fringilla coelebs & 1900 & Arad \\
Fringilla coelebs & 1907 & Arad \\
Fringilla coelebs & 1922 & Arad \\
Falco tinnunculus & 1907 & Arad \\
Alauda arvensis & 1915 & Máriaradna \\
Turdus merula & 1922 & Arad \\
\hline
\end{tabular}

In Period 2, we revealed negative correlations in the Eurasian Skylark and the House Martin. Furthermore, there were marginally significant negative correlations in the Common Starling in both periods, and in the Common Cuckoo and the Golden Oriole in Period 2 (Table 3).

\section{Overwintering species}

There are some data from overwintering species from Period 1. These species overwinter regularly nowadays, therefore it is important to note all these data (Table 4).

\section{DISCUSSION}

As a result of climate change, the distribution area (e.g. Csörgó et al. 2009), the timing of moult (Pulido \& Coppack 2004), the timing of breeding (Вотн et al. 2004) and the timing and phenology of migration (LeHiкоINen et al. 2004, ТøттRUP et al. 2006) of birds are changing. 
Although, in many cases, the results contradict each other. It is hardly possible to draw general conclusions, as the change in the timing of migration may vary by geographical area for the same species, or the pattern of migration of sibling species may give a different picture (CsörGő et al. 2009). The spring migration of several bird species in the Carpathian Basin has also changed compared to previous decades (Csörgő et al. 2009, Kiss et al. 2009, Kovács et al. 2009, Nagy et al. 2009). For some species, such as Marsh Warbler Acrocephalus palustris (CsöRGó et al. 2009), this change does not mean earlier arrival time, but on the contrary, birds arrive later to the breeding grounds. However, these studies are based on a series of data, dating back only a few decades, as standard ringing data from before the middle of the 20th century are not available to researchers. GYuRácz and BALOGH (2012) conducted similar study based on historical data, but they did not deal with the migration of birds, but with the change of their area in Vas county.

Research on historical data suggests that recently both short-term and long-term migratory birds return to nesting sites earlier than in the past (Sparks 1999, Kullberg et al. 2015). According to our results, we cannot draw general conclusions in this geographical area, as there are examples of species following both short- and long-distance migration strategies. For most longdistance migratory species, the spring arrival time has not changed, which can be explained by the fact that spring arrival in long-distance migrants is less affected by the temperature of the target area (TRYJANOwsKi et al. 2002, Hubálek 2004, Miller-Rushing et al. 2008a). Their endogenous time program is more restricted (Вотн \& Visser 2001, Сорраск \& Bотн 2002), birds are phenotypically less flexible (Pulido \& Widmer 2005) and genetic variance in migration behaviour may also be smaller in long-distance migrants (BERTHOLD \& QUeRner 1995), which may limit any micro-evolutionary response to climate change. Also, it is important to note that trans-Saharan migrants can advance spring arrival to the same extent as short-distance migrants in recent years, suggesting that onset of migration in long-distance migrants may be more flexible than previously assumed (Jonzén et al. 2006). In the case of three long-distance migratory bird species (Eurasian Hoopoe, Barn Swallow, Sand Martin), we have experienced a shift to the earlier arrival in spring. Of these species, Ambrosini et al. (2011) has shown that the wintering area shifted to the north every year, and birds can winter in places where feeding sites are less suitable (warmer, drier habitats). This is combined with the even warmer breeding sites preventing earlier departure from the wintering grounds. In the case of Eurasian Hoopoe, a slight trend to an earlier spring arrival in recent years was found by GoRDo et al. (2005) in a western Mediterranean area.

Some long-distance migrant species (Common Sandpiper, Common Cuckoo, Eurasian Wryneck, Pied Flycatcher, Lesser Grey Shrike) arrive later 
to the breeding grounds. In the case of Common Cuckoo, Gordo et al. (2005) found the same pattern in the western Mediterranean area, however, in Sweden, Kullberg et al. (2015) found that birds arrive earlier to the breeding ground recently. To explain such differences between populations, GoRDo et al. (2005) suggested that long-distance migrants are obviously unable to gather direct information about the environmental conditions in their European breeding areas, but climatic variations in sub-Saharan Africa are better predictors than local climate conditions in Europe. Namely, different European populations overwinter in different African regions under contrasting climatic constraints leading to geographic variations in the onset of migration. The Pied Flycatcher is a typical example of species not arriving earlier to Europe in recent times (ВотH \& VISSER 2001). Six out of 14 long-distance migrant species (e.g. Sedge Warbler Acrocephalus schoenobaenus, Common Whitethroat Sylvia communis) studied in Scotland between 1974 and 1999 also arrived later in spring (JENKINS \& WATSON 2000), while two shorebirds, the Lesser Yellowlegs Tringa flavipes and Greater Yellowlegs T. nebularia also arrived later to the Delta Marsh, Canada (Murphy-KLAssen et al. 2005). Our results are also consistent with these findings. In the case of the Pied Flycatcher, the main regulator of starting spring migration is the available food supply in the wintering ground, therefore the species cannot come back earlier. The background of this phenomenon may be that with the drying of wintering areas the amount of available food decreases, which results that the birds can start the migration with less and less fat, so they can move more slowly towards the breeding area (GoRdo et al. 2005, NAGy et al. 2009). Thus, their arrival in the breeding grounds will be delayed.

Short-distance migrants display a more flexible behavioural response to local weather at stopover sites (CALVERT et al. 2012) and the genetic control is also much smaller than in the case of long-distance migrants. Nine out of the 11 species arrive earlier to the study area than 100 years ago. These results are similar to the findings of Kullberg et al. (2015) in Sweden, who found that all short-distance migrants arrive earlier recently including five species studied by our work. However, in the case of Eurasian Woodcock, we found that the species arrive significantly later during Period 2. The reason for this pattern is probably the fact that the species is rarely observed during Period 2, in contrast, during Period 1, it was much easier to detect by the large number of the foresters. Somewhat surprising that there was no shift in the arrival date of Common Wood Pigeon despite the fact that the species recently regularly overwinter in the Carpathian Basin (MME Nomenclator BizotTság 2008).

Temperature and climate analyses have proven that birds, in general, respond to high temperature and positive NAO phases by arriving earlier (Lehikoinen et al. 2004). Birds cannot directly predict the conditions in the 
target area of their next flight (Lehiкoinen et al. 2004), and, in addition to temperature, many other weather parameters may play a role (ZALAKEvicius 1993, Zalakevicius et al. 1995, Sparks et al. 2002). Most studies found a negative relationship between arrival time and spring temperature (LeHIKoINEN et al. 2004, Gienapp et al. 2007). From our study species, the same pattern was detected only for the Eurasian Skylark and Common Starling in both periods. In the case of three species (Common Cuckoo, House Martin, Golden Oriole), negative correlation was found in Period 2. This might mean that some of the short-distance migrants have been able to react to the current weather a century earlier as well as nowadays, while for the long-distance migrants this pattern is typical nowadays.

The latter can be paralleled with the aforementioned statement that the long-distance migrants are much more flexible than previously thought (Jonzén et al. 2006) and are able to depart to the breeding sites sooner due to the weather conditions prevailing at wintering sites (Gordo et al. 2005). It is very interesting that in the case of Common Cuckoo we found a significant positive correlation between arrival time and temperature in Period 1.

The winter occurrences of Chaffinch and Blackbird are now quite common, with a large number of birds overwintering in the Carpathian Basin (MME Nomenclator Bizottság 2008). Although, in the second half of the 19 th century and at the beginning of the 20th century, these species were only described as forest nesters (Simonkai 1893). The author mentioned that Chaffinches also occur in winter with Crested Larks Galerida cristata and buntings along roadsides. However, urban nesting is not mentioned for any species. Thanks to milder winters, the migration habits of the Blackbirds have changed and more and more remain in the country (MórA et al. 1998), therefore also in the study site in winter (Bozó 2017b). In Common Kestrel and Eurasian Skylark, Simonkai (1893) did not mention winter occurrence, although he described both species as common breeders in the area. Consequently, it is likely that they could overwinter in the region much less often in the past than today (Bozó 2017b).

Since spring bird surveys in Period 1 had been carried out throughout the Carpathian Basin, it would be worthwhile to process these data and carry out a similar comparative analysis. All of these would be important so we could learn about the changes in species migration not only from a small local area, but from the entire Carpathian Basin.

Acknowledgement - The authors are grateful to Nikolett Olajos for the English language checking. 


\section{REFERENCES}

Ambrosini, R., Rubolini, D., Møller, A. P., Bani, L., Clark, J., Karcza, Zs., Vangeluwe, D., du Feu, C., Spina, F. \& Saino, N. (2011): Climate change and the long-term northward shift in the African wintering range of the Barn Swallow Hirundo rustica. - Climate Research 49(2): 131-141. https://doi.org/10.3354/cr01025

Berthold, P. \& Querner, U. (1995): Microevolutionary aspects of bird migration based on experimental results. - Israel Journal of Ecology and Evolution 41(3): 377-385. https:// doi.org/10.1080/00212210.1995.10688807

Berthold, P. (1996): Control of bird migration. - Chapman \& Hall, London, 355 pp.

Berthold, P. (2001): Bird migration: a general survey. 2nd ed. - Oxford University Press, Oxford, 253 pp.

Вотн, C. \& Visser, M. E. (2001): Adjustment of climate change is constrained by arrival date in a long-distance migrant bird. - Nature 411: 296-298. https://doi.org/10.1038/35077063

Both, C., Artemyev, A. V., Blahuw, B., Cowie, R. J., Deknuijzen, A. J., Eeva, T., Enemar, A., Gustafsson, L., Ivankina, E. V., Järvinen, A., Metcalfe, N. B., Nyholm, N. E. I., Potti, J. , Ravussin, P. A., Sanz, J. J., Silverin, B., Slater, F. M., Sokolov, L. V., Török, J., Winkel, W., Wright, J., ZANG, H. \& Visser, M. E. (2004): Large-scale geographical variation confirms that climate change causes bird to lay earlier. - Proceedings of the Royal Society of London B 271: 1657-1662. https://doi.org/10.1098/rspb.2004.2770

Both, C. \& Marvelde, L. (2007): Climate change and timing of avian breeding and migration throughout Europe. - Climate Research 35(1-2): 93-105. https://doi.org/10.3354/ cr00716

Bozó, L. (2017a): Történelmi madártani adatok Kevermes környékéről. - Aquila 124: 51-62. [in Hungarian]

Bozó, L. (2017b): Kevermes madárvilága. - Dél-békési Természetvédelmi és Madártani Egyesület, Kevermes, 121 pp. [in Hungarian]

ButLer, C. J. (2003): The disproportionate effect of global warming on the arrival dates of short-distance migratory birds in North America. - Ibis 145(3): 484-495. https://doi. org/10.1046/j.1474-919X.2003.00193.x

Calvert, A. M., Mackenzie, S. A., Flemming, J. M., Taylor, P. D. \& Walde, S. J. (2012): Variation in songbird migratory behavior offers clues about adaptability to environmental change. - Oecologia 168(3): 849-861. https://doi.org/10.1007/s00442-011-2119-5

Clark, R. A. \& FrID, C. L. (2001): Long-term changes in the North Sea ecosystem. -Environmental Reviews 9(3): 131-187. https://doi.org/10.1139/a01-005

Сорраск, T. \& Вотн, C. (2002): Predicting life-cycle adaptation of migratory birds to global climate change. - Ardea 90: 369-378. https://doi.org/10.5253/arde.v90i3.p369

Соттоn, P. A. (2003): Avian migration phenology and global climate change. - Proceedings of the National Academy of Sciences of the United States of America 100: 12219-12222. https://doi.org/10.1073/pnas.1930548100

Crick, H. Q., Dudley, C., Glue, D. E. \& Thomson, D. L. (1997): UK birds are laying eggs earlier. - Nature 388(6642): 526-526. https://doi.org/10.1038/41453

Csörgô, T., Harnos, A., Kovács, S. \& NAGY, K. (2009): A klímaváltozás hatásainak vizsgálata hosszú távú madárgyürüzési adatsorok elemzésével. - Természetvédelmi Közlemények 15: 1-12. [in Hungarian]

DänhARDT, J. \& Lindström, A. (2001): Optimal departure decisions ofsongbirds from an experimental stopover site and the significance of weather. - Animal Behaviour 62: 235-243. https://doi.org/10.1006/anbe.2001.1749 
Ellwood, E. R., Primack, R. B. \& Talmadge, M. L. (2010): Effects of climate change on spring arrival times of birds in Thoreau's Concord from 1851 to 2007. - The Condor 112(4): 754-762. https://doi.org/10.1525/cond.2010.100006

Ewers, R. M. \& Didham, R. K. (2006): Confounding factors in the detection of species responses to habitat fragmentation. - Biological Reviews 81(1): 117-142. https://doi. org/10.1017/S1464793105006949

GAAL, G. (1896): A madárvonulás Magyarországon az 1895. év tavaszán. A Magy. Orn. Közp. II-ik évi jelentése. - Aquila 3: 7-116. [in Hungarian]

GAAL, G. (1897): A madárvonulás Magyarországon az 1896. év tavaszán. A Magy. Orn. Közp. III. évi jelentése. - Aquila 4: 44-104. [in Hungarian]

GAAL, G. (1898): A madárvonulás Magyarországon az 1897. év tavaszán. A Magyar Ornithologiai Központ IV. évi jelentése. - Aquila 5: 226-279. [in Hungarian]

Gienapp, R., Leimu, R. \& Merilä, J. (2007): Responses to climate change in avian migration time - microevolution versus phenotypic plasticity. - Climate Research 35: 25-35. https://doi.org/10.3354/cr00712

Gordo, O., Brotons, L., Ferrer, X. \& Comas, P. (2005): Do changes in climate patterns in wintering areas affect the timing of the spring arrival of trans-Saharan migrant birds? - Global Change Biology 11(1): 12-21. https://doi.org/10.1111/j.1365-2486.2004.00875.x

Gordo, O. (2007): Why are bird migration dates shifting? A review of weather and climate effects on avian migratory phenology. - Climate Research 35(1-2): 37-58. https://doi. org/10.3354/cr00713

Greschik, J. (1910): A madárvonulás Magyarországon az 1909. év tavaszán. A Magyar Kir. Ornith. Központ XVI. évi jelentése. - Aquila 17: 1-129. [in Hungarian]

Gyurácz, J. \& BAlogh, I. (2012): Changes to the avifauna of Vas County from the 19th century to present. - International Scientific Conference on Sustainable Development \& Ecological Footprint, Sopron.

Gwinner, E. (1996): Circannual clocks in avian reproduction and migration. - Ibis 138: 4763. https://doi.org/10.1111/j.1474-919X.1996.tb04312.x

Hansen, J., Ruedy, R., SAto, M. \& Lo, K. (2005): GISS surface temperature analysis: Global temperature trends, 2005 summation. - NASA Goddard Institute for Space Studies and Columbia University Earth Institute. http://data.giss.nasa.gov/gistemp/2005/

Hansen, J., Sato, M., Ruedy, R., Lo, K., Lea, D. W. \& Medina-Elizade, M. (2006): Global temperature change. - Proceedings of the National Academy of Sciences 103(39): 1428814293. https://doi.org/10.1073/pnas.0606291103

Haunschild, R., Bornmann, L. \& Marx, W. (2016): Climate change research in view of bibliometrics. - PLoS One 11(7): e0160393. https://doi.org/10.1371/journal.pone.0160393

Неgүғоку, K. (1917): Az 1899-1916. évi tavaszi madárvonulás vidékenkint. - Aquila 24: 107-111. [in Hungarian]

HubÁLEK, Z. (2004): Global weather variability affects avian phenology: a long-term analysis, 1881-2001. - Folia Zoologica-Praha 53(3): 227-236.

Huin, N. \& Sparks, T. H. (1998): Arrival and progression of the Swallow Hirundo rustica through Britain. - Bird Study 45: 361-370. https://doi.org/10.1080/00063659809461108

Hüppop, O. \& Hüppop, K. (2003): North Atlantic Oscillation and timing of spring migration in birds. - Proceedings of the Royal Society of London Series B 270: 233-240. https://doi. org/10.1098/rspb.2002.2236

Jenkins, D. \& Watson, A. (2000): Dates of first arrival and song of birds during 1974-99 in mid-Deeside, Scotland. - Bird Study 47(2): 249-251. https://doi. org/10.1080/00063650009461183 
Jonzén, N., Lindén, A., Ergon, T., Knudsen, E., Vik, J. O., Rubolini, D., Piacentini, D., Brinch, C., Spina, F., Karlsson, L., Stervander, M., Andersson, A., Waldenström, J., Lehikoinen, A., Edvardsen, E., Solvang, R. \& Stenseth, N. C. (2006): Rapid advance of spring arrival dates in long-distance migratory birds. - Science 312(5782): 1959-1961. https://doi.org/10.1126/science.1126119

Kiss, A., Csörgô, T., Harnos, A., Kovács, Sz. \& Nagy, K. (2009): A sisegő füzike (Phylloscopus sibilatrix) vonulásának változása a klímaváltozás szempontjából. - Klíma 21 Füzetek 56: 91-99. [in Hungarian]

Knudsen, E., Linden, A., Both, C., Jonzen, N., Pulido, F., Saino, N., Sutherland, W. J., Bach, L. A., Coppack, T., Ergon, T., Gienapp, P., Gill, J. A., Gordo, O., Hedenström, A., Lehikoinen, E., Marra, P. P., Møller, A. P., Nilsson, A. L. K., Péron, G., Ranta, E., Rubolini, D., Sparks, T. H., Spina, F., Studds, C. E., Sæther, S. A., TryjanowSKI, P. \& Stenseth, N. C. (2011): Challenging claims in the study of migratory birds and climate change. - Biological Reviews 86: 928-946. https://doi.org/10.1111/j.1469185X.2011.00179.x

Kovács, S., Csörgô, T., Harnos, A. \& Nagy, K. (2009): A kerti poszáta (Sylvia borin) vonulási fenológiájának változása Ócsán az elmúlt 24 év során. - Természetvédelmi Közlemények 15: 422-433. [in Hungarian]

Kullberg, C., Fransson, T., Hedlund, J., Jonzén, N., Langvall, O., Nilsson, J. \& Bolmgren, K. (2015): Change in spring arrival of migratory birds under an era of climate change, Swedish data from the last 140 years. - Ambio 44(1): 69-77. https://doi.org/10.1007/ s13280-014-0600-1

LAmbrecht, K. (1911): A madárvonulás Magyarországon az 1910. év tavaszán. - Aquila 18: 9-134. [in Hungarian]

LAmbrecht, K. (1912): A madárvonulás Magyarországon az 1911. év tavaszán. - Aquila 19: 43-165. [in Hungarian]

LAmbrecht, K. (1913): A madárvonulás Magyarországon az 1912. év tavaszán. A Magyar Királyi Ornithologiai Központ XIX. évi jelentése. - Aquila 20: 16-145. [in Hungarian]

Lehikoinen, E., Sparks, T. H. \& Zalakevicius, M. (2004): Arrival and departure dates. Birds Climate Change 35: 1-31. https://doi.org/10.1016/S0065-2504(04)35001-4

Li, M., Xu, K., Watanabe, M. \& Chen, Z. (2007): Long-term variations in dissolved silicate, nitrogen, and phosphorus flux from the Yangtze River into the East China Sea and impacts on estuarine ecosystem. - Estuarine, Coastal and Shelf Science 71(1-2): 3-12. https://doi.org/10.1016/j.ecss.2006.08.013

LIN, C., SU, J., XU, B. \& TANG, Q. (2001): Long-term variations of temperature and salinity of the Bohai Sea and their influence on its ecosystem. - Progress in Oceanography 49(1-4): 7-19. https://doi.org/10.1016/S0079-6611(01)00013-1

MacMynowski, D. P. \& Root, T. L. (2007): Climate and the complexity of migratory phenology: sexes, migratory distance, and arrival distributions. - International Journal of Biometeorology 51(5): 361-373. https://doi.org/10.1007/s00484-006-0084-1

Macmynowski, D. P., Root, T. L., Ballard, G. \& Geupel, G. R. (2007): Changes in spring arrival of Nearctic-Neotropical migrants attributed to multiscalar climate. - Global Change Biology 13(11): 2239-2251. https://doi.org/10.1111/j.1365-2486.2007.01448.x

Magy. Orn. Központ (1895): A madárvonulás Magyarországon az 1894. év tavaszán. - Aquila 2: 3-84. [in Hungarian]

Menzel, A., Sparks, T. H., Estrella, N., Koch, E., Aasa, A., Ahas, R., Alm-Kübler, K., Bissolli, P., Braslavská, O, Briede, A., Chmielewski, F.M., Crepinsek, Z., Curnel, Y., Dahl, Å, Defila, C., Donnelly, A., Filella, Y., Jatczak, K., Måge, F., Mestre, A., 
Nordly, Ø., Peñuelas, J., Pirinen, P., Remišová, V., Scheifinger, H., Striz, M., Susnik, A., van Vliet, A. J. H., Wielgolaski, F-E., Zach, S. \& Chmielewski, F. M. (2006): European phenological response to climate change matches the warming pattern. - Global Change Biology 12(10): 1969-1976. https://doi.org/10.1111/j.1365-2486.2006.01193.x

Miller-Rushing, A. I., Lloyd-Evans, T. L., Primack, R. B. \& Satzinger, P. (2008a): Bird migration times, climate change, and changing population sizes. - Global Change Biology 14(9): 1959-1972. https://doi.org/10.1111/j.1365-2486.2008.01619.x

Miller-Rushing, A. I., Primack, R. B. \& Stymeist, R. (2008b): Interpreting variation in bird migration times as observed by volunteers. - The Auk 125: 565-573. https://doi. org/10.1525/auk.2008.07005

MME Nomenclator Bizottság (2008): Magyarország madarainak névjegyzéke. Nomenclator avium Hungariae. - Magyar Madártani és Természetvédelmi Egyesület, Budapest, 278 pp. [in Hungarian]

Møller, A. P., Nuttall, R., Piper, S. E., Szép, T. \& Vickers, E. J. (2011): Migration, moult and climate change in Barn Swallows Hirundo rustica in South Africa. - Climate Research 47(3): 201-205. https://doi.org/10.3354/cr01005

MórA, V., CsörGó, T. \& Karcza, Z. (1998): A fekete rigó (Turdus merula) túlélése a partiális vonulás tükrében. - Ornis Hungarica 8(Suppl 1): 187-198. [in Hungarian]

Murphy-Klassen, H. M., Underwood, T. J., Sealy, S. G. \& CzyrnyJ, A. A. (2005): Long-term trends in spring arrival dates of migrant birds at Delta Marsh, Manitoba, in relation to climate change. - The Auk 122(4): 1130-1148. https://doi.org/10.1093/auk/122.4.1130

NagY, K., Csörgő, T., Harnos, A. \& Kovács, Sz. (2009): A cserregő és az énekes nádiposzáta Acrocephalus scirpaceus, A. palustris vonulásának fenológiai változásai. - Természetvédelmi Közlemények 15: 434-445. [in Hungarian]

Nott, M. P., Desante, D. F., Siegel, R. B. \& Pyle, P. (2002): Influences of the El Niño/ Southern Oscillation and the North Atlantic Oscillation on avian productivity in forests of the Pacific Northwest of North America. - Global Ecology and Biogeography 11: 333-342. https://doi.org/10.1046/j.1466-822X.2002.00296.x

Olesen, J. M., Stefanescu, C. \& Traveset, A. (2011): Strong, long-term temporal dynamics of an ecological network. - PLoS One 6(11): e26455. https://doi.org/10.1371/journal. pone.0026455

Princé, K. \& Zuckerberg, B. (2015): Climate change in our backyards: the reshuffling of North America's winter bird communities. - Global Change Biology 21(2): 572-585. https://doi.org/10.1111/gcb.12740

Pulido, F. \& Widmer, M. (2005): Are long-distance migrants constrained in their evolutionary response to environmental change? Causes of variation in the timing of autumn migration in a Blackcap (Sylvia atricapilla) and two Garden Warbler (S. borin) populations. - Annals of the New York Academy of Sciences 1046(1): 228-241. https://doi. org/10.1196/annals.1343.020

Rahmstorf, S. (2008): Anthropogenic climate change: Revisiting the facts. Pp. 34-53. In: Zedillo, E. (ed.): Global warming: Looking beyond Kyoto. - Washington: Brookings Institution Press.

Schenk, J. (1899): A madárvonulás Magyarországban az 1898. év tavaszán. A Magyar Ornithologiai Központ V. évi jelentése. - Aquila 6: 168-251. [in Hungarian]

Schenk, J. (1901): A madárvonulás Magyarországon az 1899. év tavaszán. A Magyar Ornithologiai Központ VI. évi jelentése. - Aquila 8: 50-122. [in Hungarian]

Schenk, J. (1905): A madárvonulás Magyarországon az 1903. év tavaszán. A Magy. Ornith. Központ X. évi jelentése. - Aquila 12: 83-202. [in Hungarian] 
Schenk, J. (1906): A madárvonulás Magyarországon az 1904. év tavaszán. A Magyar Ornith. Központ XI. évi jelentése. - Aquila 13: 9-66. [in Hungarian]

Schenk, J. (1907): A madárvonulás Magyarországon az 1906. év tavaszán. A Magyar Ornith. Központ XIII. évi jelentése. - Aquila 14: 1-119. [in Hungarian]

Schenk, J. (1908): A madárvonulás Magyarországon az 1907. év tavaszán. A Magyar Ornith. Központ XIV. évi jelentése. - Aquila 15: 1-152. [in Hungarian]

Schenk, J. (1909): A madárvonulás Magyarországon az 1908. év tavaszán. A Magyar Kir. Ornith. Központ XV. évi jelentése. - Aquila 16: 1-128. [in Hungarian]

Schenk, J. (1914): A madárvonulás Magyarországon az 1913. év tavaszán. A Magyar Királyi Ornithologiai Központ XX. évi jelentése. - Aquila 21: 137-187. [in Hungarian]

Schenk, J. (1915): A madárvonulás Magyarországon az 1914. év tavaszán. A Magyar Királyi Ornithologiai Központ XXI. évi jelentése. - Aquila 22: 5-56. [in Hungarian]

Schenk, J. (1916): A madárvonulás Magyarországon az 1915. és 1916. év tavaszán. A Magyar Királyi Ornithologiai Központ XXII. és XXIII. évi jelentése. Befejező közlemény. - Aquila 23: 13-49. [in Hungarian]

Schenk, J. (1919): Madárvonulási adatok Magyarországból. II. - Aquila 26: 46-75. [in Hungarian]

Schenk, J. (1920): Madárvonulási adatok Magyarországból. III. - Aquila 27: 39-55. [in Hungarian]

Schenk, J. (1921): Madárvonulási adatok Magyarországból. IV. - Aquila 28: 97-126. [in Hungarian]

SIIкAмÄкI, P. (1998): Limitation of reproductive success by food availability and breeding time in Pied Flycatchers. - Ecology 79(5): 1789-1796. https://doi.org/10.1890/00129658(1998)079[1789:LORSBF]2.0.CO;2

SimonkaI, L. (1893): Arad vármegye és Arad Szabad Királyi Város természetrajzi leírása. Harmadik rész. Aradmegye és Aradváros állatvilága. - Arad, Monographia-Bizottság, 141 pp. [in Hungarian]

Smith, R. J. \& Moore, F. R. (2005): Arrival timing and seasonal reproductive performance in a long-distance migratory landbird. - Behavioral Ecology and Sociobiology 57(3): 231239. https://doi.org/10.1007/s00265-004-0855-9

SPARKs, T. H. (1999): Phenology and the changing pattern in bird migration in Britain. - International Journal of Biometeorology 42: 134-138. https://doi.org/10.1007/s004840050096

Sparks, T., Crick, H., Elkins, N., Moss, R., Moss, S. \& Mylne, K. (2002): Birds, weather and climate. - Weather 57(11): 399-410. https://doi.org/10.1256/wea.142.02

Tøtтrup, A. P., Thorup, K. \& Rahbeк, C. (2006): Patterns of change in timing of spring migration in North European songbird populations. - Journal of Avian Biology 37: 84-92. https://doi.org/10.1111/j.0908-8857.2006.03391.x

TryjAnowski, P. \& Sparks, T. H. (2001): Is the detection of the first arrival date of migrating birds influenced by population size? A case study of the Red-backed Shrike Lanius collurio. - International Journal of Biometeorology 45: 217-219. https://doi.org/10.1007/ s00484-001-0112-0

Tryjanowski, P., KuZniak, S. \& Sparks T. (2002): Earlier arrival of some farmland migrants in western Poland. - Ibis 144: 62-68. https://doi.org/10.1046/j.0019-1019.2001.00022.x

Van Buskirk, J., Mulvihill, R. S. \& Leberman, R. C. (2009): Variable shifts in spring and autumn migration phenology in North American songbirds associated with climate change. - Global Change Biology 15(3): 760-771. https://doi.org/10.1111/j.13652486.2008.01751.x 
VezéNYI, Á. (1902): A madárvonulás Magyarországon az 1900. év tavaszán. A Magyar Ornithologiai Központ VII. évi jelentése. - Aquila 9: 81-155. [in Hungarian]

VezéNYI, Á. (1903): A madárvonulás Magyarországon az 1901. év tavaszán. A Magy. Ornith. Központ VIII. évi jelentése. - Aquila 10: 104-187. [in Hungarian]

VezénYI, Á. (1905): A madárvonulás Magyarországon az 1902. év tavaszán. A Magy. Ornith. Központ IX. évi jelentése. - Aquila 12: 1-77. [in Hungarian]

Visser, M. E., Noordwijk, A. V., Tinbergen, J. M. \& Lessells, C. M. (1998): Warmer springs lead to mistimed reproduction in Great Tits (Parus major). - Proceedings of the Royal Society of London. Series B: Biological Sciences 265(1408): 1867-1870. https://doi. org/10.1098/rspb.1998.0514

Warga, K. (1922): Madárvonulási adatok Magyarországból. - Aquila 29: 91-131. [in Hungarian]

WargA, K. (1924): Madárvonulási adatok Magyarországból. - Aquila 30-31: 179-237. [in Hungarian]

Warga, K. (1926): Madárvonulási adatok Magyarországból. - Aquila 32-33: 66-127. [in Hungarian]

WARGA, K. (1928): Madárvonulási adatok Magyarországból. X. (1926-os) évfolyam. - Aquila 34-35: 257-305. [in Hungarian]

Woodwell, G. M. (1970): Effects of pollution on the structure and physiology of ecosystems. - Science 168(3930): 429-433.

Zalakevicius, M. (1993): Mechanisms controlling migratory take-off in spring and autumn. Acta Ornithologica Lituanica 7: 16-26.

Zalakevicius, M., Svazas, S., Stanevicius, V. \& Vaitkus, G. (1995): Bird migration \& wintering in Lithuania: a monograph. - Acta Zoologica Lituanica 2: 252.

https://www.arcanum.hu

https://www.met.hu/eghajlat/magyarorszag_eghajlata/eghajlati_adatsorok/Szeged/adatok/napi_adatok/index.php

Received June 18, 2019, accepted April 22, 2020, published August 14, 2020 